\title{
USE OF ALPHA AND BETA ADRENERGIC BLOCKING DRUGS AND HALOTHANE IN THE ANAESTHETIC MANAGEMENT OF PHAEOCHROMOCYTOMA
}

\author{
D. M. GEBBIE, M.B., CH.B., AND D. C. FINLAYSON, M.D., F.R.C.P.(c)
}

Priafochromocytoma, although relatively uncommon, remains of great interest to medicine and has been extensively reported. An attempt at review is out of place here. However, recent work on the metabolism of catecholamines ${ }^{1,2}$ and of the action of alpha and beta adrenergic receptor blocking drugs ${ }^{3}$ may provide useful approaches for safer management of these tumour's. To illustrate this, histories of four patients having five anaesthetics and surgical explorations will be presented.

1. D.D. This fifty-three-year-old female was admitted for evaluation of atherosclerotic cardiac and peripheral vascular disease. Translumbar aortography revealed a large right suprarenal tumour in addition to femoral arterial obstruction. This, along with the history of palpitations and anxiety, and the findings of labile hypertension, a positive phentolamine test, and VMA of $44 \mathrm{mg}$. per cent in 24 hours, led to the diagnosis of phaeochromocytoma. In preparation for operation, the patient received oral phentolamine in a gradually increasing dose which reached $50 \mathrm{mg}$. q.6h. for three days. She was digitalized, given one unit of whole blood preoperatively, and premedicated with phentolamine 50 $\mathrm{mg}$., pentobarbitone $100 \mathrm{mg}$, and atropine $0.4 \mathrm{mg}$. Immediately before surgery an infusion containing phentolamine 0.01 per cent $(0.1 \mathrm{mg} / \mathrm{c} . \mathrm{c}$. $)$ and syringes containing phentolamine one mg./c.c. and propranolol $1.0 \mathrm{mg} . / \mathrm{c} . c$. were prepared. A cardioscope was connected, and percutaneous intravenous cannulae were placed for infusions and venous pressure monitoring. Anaesthesia was induced with thiopentone $200 \mathrm{mg}$., nitrous oxide, oxygen, and halothane. About fifteen minutes later, on achievement of a surgical level of anaesthesia, succinylcholine $\mathbf{4 0} \mathrm{mg}$. was given and the trachea was intubated. D-tubocurare was used for relaxation. As the dissection approached the tumour, propranolol was given in divided doses to a total of $1.75 \mathrm{mg}$. and the phentolamine infusion was begun. With the exception of one brief episode of ventricular premature beats during handling of the tumour and, following complete removal of the tumour, a moderate fall in blood pressure from 120 to $80 \mathrm{~mm}$. systolic lasting a minute or so, the patient's peroperative course was entirely uneventful. The hypotension was managed by infusing a further unit of blood and 1000 c.c. of a balanced salt solution. The postoperative course was uneventful, and when she was seen for a follow-up examination two months later, the patient's blood pressure was $140 / 90$.

2. E.S. This fifty-three-year-old female was admitted for investigation of hypertension of several years' duration associated with periodic bouts of palpitations,

-Department of Anaesthesia, University of Toronto and St. Michael's Hospital, Toronto, Ontario. 
in one of which a blood pressure of $270 / 140$ was recorded. Investigation revealed a positive phentolamine test; a right suprarenal tumour by aortography, and a VMA excretion of $24.8 \mathrm{mg}$. per 24 hours. Preoperative preparation was with oral phentolamine $50 \mathrm{mg}$. every four hours for six days. Premedication consisted of pentobarbitone $200 \mathrm{mg}$, demerol $50 \mathrm{mg}$, atropine $0.4 \mathrm{mg}$, and phentolamine $50 \mathrm{mg}$. Anaesthesia was induced with thiopentone $125 \mathrm{mg}$, nitrous oxide, oxygen, and halothane. When anaesthesia was established, $40 \mathrm{mg}$. succinylcholine was given and the trachea was intubated using topical lignocaine. D-tubocurare was used for relaxation. A phentolamine infusion was started, and, with propranolol, the bouts of hypertension and tachycardia occurring with exploration and tumour dissection were easily controlled. A total of $2 \mathrm{mg}$. of propranolol was given. The postoperative course was uneventful and the patient was discharged with a blood pressure of 120/90.

3. G.D. A forty-two-year-old female was admitted for investigation of an elevated blood pressure of eighteen months' duration with associated sweating, nausea, headaches, and palpitations. A VMA excretion of $25 \mathrm{mg}$. in 24 hours, a positive phentolamine test, and an aortogram showing a left suprarenal mass were demonstrated. Preoperative preparation consisted of phentolamine $25 \mathrm{mg}$. every 6 hours, increasing over 8 days to $100 \mathrm{mg}$. every 4 hours on the day prior to surgery. The haematocrit fell from 31 to 29 per cent and rose to 40 per cent following transfusion with one unit of packed cells. A progressive tachycardia developed with the heart rate persistently above 120 . Premedication consisted of morphine $10.0 \mathrm{mg}$., pentobarbitone $100 \mathrm{mg}$., scopolamine $0.4 \mathrm{mg}$., and phentolamine $100 \mathrm{mg}$. Anaesthesia was induced with thiopentone $75 \mathrm{mg}$., nitrous oxide, oxygen, and halothane. Intubation was accomplished using topical lignocaine and succinylcholine $60 \mathrm{mg}$. D-tubocurare was used for relaxation. With intermittent doses of propranolol and a phentolamine infusion, no arrythmias were encountered. On removal of the tumour the blood pressure fell from 190/130 to $110 / 90$ but within a few hours of emergence from anaesthesia it had risen again to $210 / 150$. Further studies demonstrated a second phaeochromocytoma present in the lumbar area. This was removed three weeks later. The preparation and anaesthesia were managed in the same way except for the use of a succinylcholine infusion for relaxation. During surgery no phentolamine or propranolol was used and the peroperative course was uneventful. Regional lymph nodes were found to be involved and the patient again became moderately hypertensive following operation. A phentolamine test was again positive. Dibenzyline $30 \mathrm{mg}$. was given twice daily, orally, as soon as oral feedings were tolerated, and after some three weeks on this medication, the patient was discharged with a blood pressure of $110 / 90$.

4. $L . W$. This nineteen-year-old girl was admitted for evaluation of intermittent palpitations, dyspnoea, muscular aching, and profuse sweating of two years' duration with associated elevation of the blood pressure. Physical examination was unremarkable except for a blood pressure of 170/95, a pulse rate of 104, slight cardiac enlargement, and a precordial systolic murmur. Laboratory studies revealed 24-hour V.M.A. excretions of 24 and $29 \mathrm{mg}$.

Preoperative preparation consisted of oral phentolamine $25 \mathrm{mg}$., four hourly, with the last dose given two hours preoperatively, accompanied by pentobarbitone 
$200 \mathrm{mg}$, demerol $75 \mathrm{mg}$, and atropine $0.4 \mathrm{mg}$. Anaesthesia was induced with thiopentone $150 \mathrm{mg}$., nitrous oxide, oxygen, and halothane. The trachea was intubated with the aid of $75 \mathrm{mg}$. of succinylcholine after stable surgical anaesthesia had been achieved. D-tubocurarine was used for relaxation.

The patient was given phentolamine in intermittent doses and by a continuous 0.01 per cent infusion. Propranolol in $0.2 \mathrm{mg}$. increments to a total of $1.6 \mathrm{mg}$. was given over a one-hour period. Under this medication, except for a brief episode of atrial and ventricular premature beats at the beginning of the tumour dissection, the cardiovascular system was stable throughout. A right suprarenal phaeochromocytoma was removed. On ligation of the pedicle the patient's blood pressure fell to and remained at normal levels.

\section{Discussron}

There are several features in the management of these patients which should be emphasized. The acute effects of the tumour catechols on various body systems can today, for the most part, be adequately blocked pharmacologically at the target organ, by blocking its alpha and beta adrenergic receptors. As well as the dibenzylene and phentolamine that we have had for many years, beta adrenergic blocking drugs such as propranolol are now available. In combination they permit the use of any type of anaesthetic technique or agent and greatly simplify fluid repletion and the maintenance of a stable cardiovascular system. Although, in the future, metabolic inhibition of catechol biosynthesis by drugs like alpha-methyl-tyrosine may be possible, ${ }^{4}$ at present the adrenergic blocking drugs offer the best tools for the control of this tumour and should be used.

Alpha blockade should be instituted several days preoperatively and should reach adequate levels before surgery is undertaken. 5 For this purpose we have used phentolamine orally in increasing doses ranging from 25 to $100 \mathrm{mg}$. every four hours. Adequacy can be assessed by: (1) a return of the blood pressure to normotensive levels, (2) increased well-being in the patient, and (3) an enlargement of the blood volume as measured by dilutional techniques or a fall in the haematocrit. For use during operation the phentolamine was prepared as (1) an infusion of $50 \mathrm{mg}$. $/ 500$ c.c., and (2) a $1 \mathrm{mg} . / \mathrm{c.c}$. mixture for supplemental injection. During this period of preparation one may see postural hypotension and tachycardia due to the effects of the unantagonized epinephrine. The former will be satisfactorily controlled by bed rest and the latter by the use of oral propranolol in increasing doses which would probably range from 10 to $20 \mathrm{mg}$. every 6 to 8 hours. $^{6}$ It should probably have been given to patient G.D. preoperatively.

The ability of propranolol to control tachycardia and myocardial irritability is of great value during operation as well as preoperatively. During operation we found that satisfactory control was achieved using $0.25 \mathrm{mg}$. increments, and our total doses in these patients ranged from 1.25 to $2 \mathrm{mg}$. The effect appeared to need reinforcement in approximately 45 minutes.

Halothane, although not normally recommended in this condition, proved satisfactory in our hands. Two factors were considered in this choice. First, 
it has been demonstrated, in a patient with a phaeochromocytoma, that a progressive fall in the levels of circulating catechols can occur, directly related to the depth of anaesthesia with halothane. ${ }^{7}$ Secondly, the arrhythmias due to sensitization of the myocardium by this agent are readily controlled by beta adrenergic blocking drugs. ${ }^{8}$

In management of anaesthesia one should be aware that induction is a critical period, 9 and that the common anaesthetic induction with thiopentone followed by succinylcholine and intubation of the trachea may elicit a brisk autonomic sympathetic response. In these patients this may be extremely hazardous. In order to use this approach, we believe the patient should be prepared preoperatively with propranolol. Failing this, the alternative, and in retrospect not necessarily the most desirable alternative, is the use of sufficient thiopentone and inhalational agents to carry the patient to deeper levels of surgical anaesthesia in order to minimize the response to intubation.

In the past, following removal of the tumour one customarily expected persistent hypotension, necessitating a vasopressor infusion. As physiological knowledge has advanced we realize, and these patients again demonstrate, that with appropriate hydration this hypotension will not occur. Should hypotension develop it will likely be due to inadequate hydration and will quickly respond to the rapid infusion of electrolyte solution whose infusion rate and volume can be monitored using the venous pressure. It should be emphasized that hypotension is not an indication for a vasopressor, nor is it an indication for the excessive infusion of blood. Operative blood loss should only be replaced with an amount equal to that lost.

\section{SUMMARY}

Recent work with the adrenergic blocking drugs has made it possible to block the alpha and beta effects of the catecholamines in phaeochromocytoma. This permits much wider latitude in the choice of anaesthetic techniques and agents. Four patients are presented in which these drugs were used preoperatively and during operation in combination with halothane for the management of anaesthesia.

\section{RÉSUMÉ}

Le phéochromocytome, bien que relativement peu fréquent, demeure d'un grand intérêt en médecine. De récents travaux avec les médicaments bloquers adrénergiques ont abouti à la fabrication du propranolol pour bloquer les récepteurs beta. Les bloqueurs des récepteurs alpha et beta, utilisés ensemble, permettent de controler l'irritabilité du myocarde et les effets hypertenseurs des tumeurs à catécholamines. Ils permettent également un plus grand choix des agents et des techniques anesthésiques. Ce travail illustre l'usage des bloqueurs alpha et beta, avant et au cours de l'opération, et de l'halothane dans la conduite de l'anesthésie chez quatre de ces malades. Dans tous les cas, nous avons obtenu un état stable durant toute l'opération. 


\section{REFERENCES}

1. Wortman, R. J. Catecholamines. New England J. Med. 273, 637, 693, 746 (1965).

2. Spector S.; SJoErdsma, A.; \& Udenfriend S. Blockade of Endoginous Norepinephrine Synthesis by Alpha Methyl-Tyrosine, an Inhibitor of Tyrosine Hydroxylose. J. Pharmacol. Exper. Therap. 147: 86 (1965).

3. Black, J. W.; Growthen, A. F.; Shanks, R. G.; Smith, L. H.; \& Dornhurst, A. C. A New Adrenergic Beta-receptor Antagonist. Lancet. 1: 1080 (1964).

4. Engedman, K. \& Sjoerrdsma, A. Inhibition of Catecholamine Biosynthesis in Man. Circ. Res. 18, 19 (Suppl. 1): 1 (1966).

5. GoLDFIEN, A. Pheochromocytoma: Diagnosis and Anesthetic and Surgical Management. Anesthesiology. 24: 462 (1963).

6. Dornhorst, A. C. \& Laurence, D. R. Use of Pronethalol in Phaeochrome Tumours. Brit. M. J. 2: 1250 ( 1963 ).

7. Etsten, B. E. \& Stmmosato, S. Halothane Anesthesia and Catecholamine Levels in a Patient with Pheochromocytoma. Anesthesiology. 26: 688 (1965).

8. Hess, J. M. \& HaMpton, L. J. Prevention of Epinephrine-Halothane Arrhythmias by Adrenergic Beta Receptor Blockade. Anesthesiology. 25: 101 (1964).

9. Robertson, A. I. G. Pre- and Post-operative Care in Patients with Phaeochromocytomas. Postgrad. M. J. 41 : 481 (1965). 